\title{
APPle Yield MAPPing By APPliCATion OF THERMAL IMAGE ANALYSIS
}

\author{
StAJNKO, D.; Vindis, P.; MuRseC, B.; \\ BRUS, M. \& JANZEKOVIC, M.
}

Abstract: A new thermal imaging based technique for estimating number, diameter and yield of apple fruits automatically under natural condition in the orchard was tested in the apple orchard for three years (2005-2007). Each time thirty apple trees were recorded from both sides of the row. Video signals from the camera were digitised using frame grabber and the images were processed off-line using several image processing algorithms. The system was proved successfully for estimating the number of fruits on trees ( $R^{2} 0.70$ to 0.93$)$, measuring the fruit's diameter $\left(R^{2} 0.77\right.$ to $0.88)$ and estimating of the yield per tree ( $R^{2} 0.69$ to 0.79). The thermal camera was demonstrated as a suitable instrument for estimating the future yield in the whole orchards, since the index between the forecasted and harvested yield varied only between 0.93 and 1.11, which may help the fruit-grower usefulyl for preparing himself for the coming harvesting season.

Key words: thermal camera, image analysis, apple yield, forecast
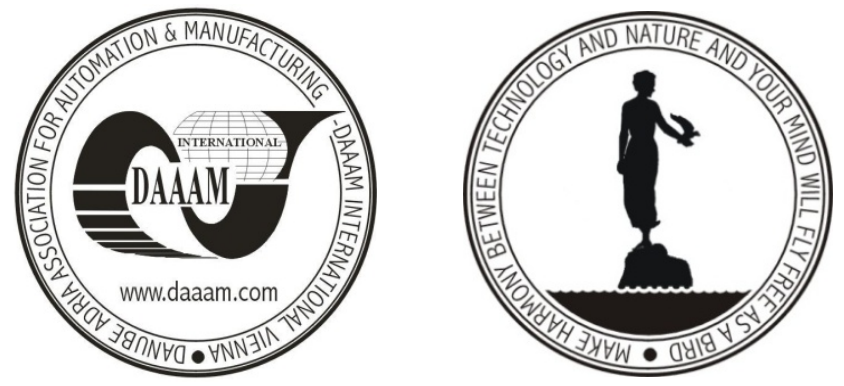

Authors' data: Assist. Prof. Dr. Stajnko, D[enis]; Vindis, P[eter]; Prof. Dr. Mursec, B[ogomir]; Brus, M[aksimilijan]; Assist. Prof. Dr. Janzekovic, M[arjan], University of Maribor, Faculty of Agriculture and Life Sciences, Vrbanska 30, 2000, Maribor, SI, denis.stajnko@uni-mb.si, peter.vindis@uni-mb.si, bogomir.mursec@uni-mb.si, maksimiljan.brus@uni-mb.si,marjan.janzekovic@uni-mb.si

This Publication has to be referred as: Stajnko, $\mathrm{D}$ [enis]; Vindis, $\mathrm{P}$ [eter]; Mursec, B[ogomir]; Brus, M[aksimiljan] \& Janzekovic, M[arjan] (2008). Apple Yield Mapping by Application of Thermal Image Analysis, Chapter 67 in DAAAM International Scientific Book 2008, pp. 827-838, B. Katalinic (Ed.), Published by DAAAM International, ISBN 978-3-901509-66-7, ISSN 1726-9687, Vienna, Austria DOI: $10.2507 /$ daaam.scibook.2008.67 